\title{
Dynamic Regulation of Expression and Phosphorylation of Tau by Fibroblast Growth Factor-2 In Neural Progenitor Cells from Adult Rat Hippocampus
}

\author{
Yoshitaka Tatebayashi, Khalid Iqbal, and Inge Grundke-Iqbal \\ New York State Institute for Basic Research in Developmental Disabilities, Staten Island, New York 10314
}

The nature of the extracellular signals that regulate the expression and the phosphorylation of the microtubule-associated protein tau, which is aberrantly hyperphosphorylated in Alzheimer disease and other adult-onset neurodegenerative diseases, is not known. We have found that neural progenitor cells from adult rat hippocampus express adult isoforms of tau and that the expression and the phosphorylation of tau are regulated by fibroblast growth factor-2 (FGF-2). Astrocytes that are differentiated from these cells by stimulation with ciliary neurotrophic factor express phosphorylated tau similarly when cultured in the presence of FGF-2. In fetal progenitor cells that express only the fetal tau isoform, expression, but not the phosphorylation, of this protein is regulated by FGF-2 in cul- tures of higher passages. The FGF-2-mediated tau hyperphosphorylation is inhibited by lithium, an inhibitor of glycogen synthase kinase-3 (GSK-3), but not by inhibitors of mitogenactivated protein kinase or the cyclin-dependent kinases. Furthermore, both GSK-3 activity and the phosphorylation of tau increase when the concentration of FGF-2 is increased up to 40 $\mathrm{ng} / \mathrm{ml}$. These results demonstrate that proliferating adult rat hippocampal progenitor cells express adult isoforms of tau stably and that FGF-2 upregulates the expression and, by upregulating GSK-3 activity, the phosphorylation of tau.

Key words: tau; fibroblast growth factor-2; glycogen synthase kinase-3; neural progenitor cells; phosphorylation; adult tau isoforms; Alzheimer Disease
Neural progenitor (or stem) cells are multipotential precursor cells that can give rise to both neurons and glia in the fetal and adult CNS (for review, see McKay, 1997). Most of the progenitor cells from adult hippocampus expanded by fibroblast growth factor-2 (FGF-2) are immunohistochemically positive for the intermediate filament nestin, the neuronal marker microtubuleassociated protein-2C (MAP-2C), neuron-specific enolase, and the immature glial marker $\mathrm{O} 4$, but only a few of the cells have been found to be positive for markers of differentiation such as glial fibrillary acidic protein (GFAP), myelin basic protein, or neurofilament H (Gage et al., 1995; Palmer et al., 1997). However, little is known about the expression of the neuronal MAP tau in these progenitor cells. The expression of tau is regulated developmentally; i.e., whereas in adult mammalian brain several isoforms are produced from a single gene by alternative splicing, in fetal brain only a single isoform is expressed that corresponds to the smallest of the tau isoforms (Lee et al., 1988; Goedert et al.,

Received Nov. 11, 1998; revised March 23, 1999; accepted April 13, 1999.

These studies were supported in part by funds from the New York State Office of Mental Retardation and Developmental Disabilities and National Institutes of Health Grants NS18105, AG05892, and AG08076. We thank Tanweer Zaidi and Qiongli Wu of our laboratory for the preparation of AD P-tau and recombinant human tau isoforms. We gratefully acknowledge Dr. Ronald D.G. McKay (National Institute of Neurological Disorders and Stroke, Bethesda, MD) for a gift of polyclonal antibody to nestin \#133, Dr. Lester I. Binder (University of Alabama, Birmingham, AL) for a generous supply of monoclonal antibody Tau-1, Dr. Peter Davies (Albert Einstein College of Medicine, Bronx, NY) for PHF-1, Dr. Jesus Avila (Universidad Autónoma de Madrid, Madrid, Spain) for antibody 972, Dr. Yasuo Ihara (University of Tokyo, Tokyo, Japan) for M4 antibody, and Dr. Dale Schenk (Athena Neurosciences, San Francisco, CA) for 12E8 antibody. We also thank the Biomedical Photography Unit for the preparation of the figures, Ms. Maureen Marlow for editorial assistance, and Ms. Janet Biegelson and Ms. Sonia Warren for secretarial assistance.

Correspondence should be addressed to Dr. Inge Grundke-Iqbal, New York State Institute for Basic Research in Developmental Disabilities, 1050 Forest Hill Road, Staten Island, NY 10314.

Copyright (C) 1999 Society for Neuroscience $\quad 0270-6474 / 99 / 195245-10 \$ 05.00 / 0$
1989; Kosik et al., 1989). One of the most important posttranslational modifications of tau is phosphorylation, because the degree of phosphorylation regulates its biological activity (Lindwall and Cole, 1984). Normal adult tau, which contains two to three phosphate groups, promotes the assembly of microtubules in vitro, and fetal tau, which is hyperphosphorylated to an intermediate degree, has less activity (Yoshida and Ihara, 1993). In Alzheimer disease (AD), tau is hyperphosphorylated abnormally (Grundke-Iqbal et al., 1986a,b; Iqbal et al., 1986). It contains up to 9 mol of phosphate per mole of the protein (Köpke et al., 1993) and is microtubule assembly-incompetent (Alonso et al., 1994; Iqbal et al., 1994).

In the present study, using adult hippocampal progenitor cells expanded by FGF-2, we demonstrate for the first time that these cells express adult isoforms of tau that are phosphorylated, especially at Ser 195/198/199/202, the Tau-1 site. Interestingly, in these cells, FGF-2 upregulates the expression and phosphorylation of tau at the Tau-1 site. We show that the mechanism of the hyperphosphorylation of tau by FGF-2 involves the upregulation of the glycogen synthase kinase-3 (GSK-3) activity; the mitogenactivated protein kinase (MAPK) and cyclin-dependent kinase (cdk) pathways are not involved in this mechanism. On the other hand, fetal hippocampal progenitor cells expanded by FGF-2 express only the fetal isoform of tau for which the expression is regulated by FGF-2, but only in the late passages, and FGF-2 has no effect on its phosphorylation. Thus, FGF-2 is the first identified extracellular regulator for expression and phosphorylation of tau in neural cells derived from adult CNS.

\section{MATERIALS AND METHODS}

Antibodies, enzyme inhibitors, isolation of tau. The following phosphorylation-dependent, site-specific monoclonal and phosphorylationindependent polyclonal antibodies to tau were used: Tau-1 (to unphos- 
phorylated Ser 195, 198, 199, or 202; numbers according to the longest human tau isoform, corresponding to Ser 186, 189, 190, or 193 in the longest rat tau isoform; ascites, 1:50,000) (Binder et al., 1985; GrundkeIqbal et al., 1986a; Szendrei et al., 1993); PHF-1 (to phosphorylated Ser 396/404 in human and Ser 387/395 in rat; culture supernatant, 1:100) (Greenberg et al., 1992; Otvos et al., 1994); M4 (to phosphorylated Thr 231/Ser 235 in human and Thr 222/Ser 226 in rat; ascites, 1:2000) (Hasegawa et al., 1993); 12E8 (to phosphorylated Ser 262/356 in human and Ser 253/347 in rat; $1 \mu \mathrm{g} / \mathrm{ml}$ ) (Seubert et al., 1995); rabbit antisera to isolated bovine tau, 92e (1:5000; Grundke-Iqbal et al., 1988); and to recombinant human tau $410,134 \mathrm{~d}$ [1:5000; raised according to the method in Grundke-Iqbal et al. (1988)]. Other primary antibodies used were monoclonal antibody SMI 33 to dephosphorylated neurofilaments $\mathrm{H}$ and M (1:1000; Sternberger Monoclonals, Baltimore, MD); monoclonal antibody DM1A to $\alpha$-tubulin (1:2000; Sigma, St. Louis, MO); polyclonal antibody 972 to dephosphorylated MAP-2A-C (1:10,000; Sánchez et al., 1995); monoclonal and polyclonal antibodies to GFAP, monoGFAP (1:1000; Boehringer Mannheim, Indianapolis, IN), poly-GFAP (1:2000; Dako, Carpinteria, CA), monoclonal antibodies to nestin, Rat401 (1:1000; PharMingen, San Diego, CA), and rabbit antiserum to nestin \#130 (1:1000; Tohyama et al., 1992); and rabbit antiserum R133d to GSK-3 (1:500; Pei et al., 1997). The secondary antibodies used were goat anti-mouse $\operatorname{IgG}(1: 100)$, followed by Clono PAP (1:100), both purchased from Sternberger (Jarrettsville, MD); ${ }^{125}$ I-conjugated antimouse and anti-rabbit IgG antibodies $(0.1 \mu \mathrm{g} / \mathrm{ml}$; Amersham, Arlington Heights, IL) for radio immunoblots; Oregon Green 488-labeled goat anti-mouse (1:1000; Molecular Probes, Eugene, OR) and Texas Redlabeled goat anti-rabbit IgG antibodies (1:2000; Molecular Probes) for immunocytochemistry. PD 98059, butyrolactone I, and $\mathrm{LiCl}$ were purchased from Calbiochem (La Jolla, CA), Biomol (Plymouth Meeting, PA), and Sigma, respectively. Recombinant human taus, tau ${ }_{410}$ (tau 39, three-repeat tau with two N-terminal inserts), $\operatorname{tau}_{383}$ (tau 24, four-repeat tau without $\mathrm{N}$-terminal inserts), and $\operatorname{tau}_{352}$ (tau 23, three-repeat tau without $\mathrm{N}$-terminal inserts) were prepared as previously described (Singh et al., 1995b). Hyperphosphorylated tau (AD P-tau) was purified from Alzheimer brain as described previously (Köpke et al., 1993).

Isolation of adult hippocampal progenitor cells. Approximately 3-monthold rats were killed by lethal injection of Nembutal $(200 \mathrm{mg} / \mathrm{kg}$ body weight; Abbott Laboratories, North Chicago, IL); the hippocampus was dissected, and the cells were dissociated according to the slightly modified method of Brewer (1997). Dissected hippocampus was cut into small $\left(\sim 0.5 \mathrm{~mm}^{3}\right)$ pieces with a razor blade in Hibernate A containing $2 \%$ B27 supplement and $0.5 \mathrm{~mm}$ glutamine at $4^{\circ} \mathrm{C}$ (all of which were purchased from Life Technologies, Grand Island, NY). The tissue pieces were digested with $2 \mathrm{mg} / \mathrm{ml}$ papain (Worthington, Freehold, NJ) in Hibernate $\mathrm{A} / \mathrm{B} 27$ for $30 \mathrm{~min}$ at $30^{\circ} \mathrm{C}$ with shaking on a reciprocal shaker at $170 \mathrm{rpm}$, washed gently with warm Hibernate A/B27 once, and dissociated in three $2 \mathrm{ml}$ volumes of Hibernate A/B27 by brief mechanical trituration with a siliconized Pasteur pipette. To remove debris, we layered the resulting $6 \mathrm{ml}$ of cell suspension over a $4 \mathrm{ml}$ step density gradient (Optiprep, Life Technologies; at 7, 9.4, 11.7, and 16.4\%, $1 \mathrm{ml}$ each, in Hibernate A/B27) and centrifuged it at $800 \times g$ at room temperature for $15 \mathrm{~min}$. The top $7 \mathrm{ml}$ of the supernatant that contained only debris was discarded, and the remaining $3 \mathrm{ml}$ of supernatant, including the dense band of cells and some debris and the pellet, were collected together and diluted in $5 \mathrm{ml}$ of Hibernate A/B27. After $5 \mathrm{~min}$ of centrifugation at $800 \times g$, the cell pellet was resuspended in Neurobasal A $(12.5 \mathrm{~mm} \mathrm{NaCl}$ plus Neurobasal; Life Technologies) containing 2\% B27 supplement and $0.5 \mathrm{~mm}$ glutamine, and $1 \times 10^{6}$ of cells were plated onto glass slides precoated with $0.01 \%$ poly-L-lysine $(135 \mathrm{kDa}$; Sigma). Cultures were incubated at $37^{\circ} \mathrm{C}$ with $5 \% \mathrm{CO}_{2}$ for $1 \mathrm{hr}$. Then the slides were washed once with warm Neurobasal A/B27 to remove debris and were cultured with Neurobasal A/B27 containing $0.5 \mathrm{~mm}$ glutamine, $100 \mathrm{IU} / \mathrm{ml}$ of penicillin, $100 \mu \mathrm{g} / \mathrm{ml}$ of streptomycin, and $5 \mathrm{ng} / \mathrm{ml} \mathrm{FGF-2} \mathrm{(Life} \mathrm{Technol-}$ ogies). Half of the medium was changed to new medium with a double amount of fresh FGF-2 every 3-4 d, and the cells were passaged at $70-90 \%$ confluency by incubating them briefly in warm PBS and scraping them with a cell scraper. After the third passage the plates were precoated with $1 \mu \mathrm{g} / \mathrm{ml}$ of fibronectin (Life Technologies) in addition to $0.01 \%$ poly-L-lysine; the FGF-2 concentration in the medium was increased to $10 \mathrm{ng} / \mathrm{ml}$. Cultures from the fifth to eleventh passages were used for this study.

Isolation of fetal hippocampal progenitor cells. Fetal hippocampal progenitor cells were isolated and expanded according to the slightly modified method of Johe et al. (1996). Briefly, rat fetal hippocampus (gesta- tion day 16; day of conception is day 1) was dissected in Hibernate A/B27 and dissociated by brief trituration in the same medium. The cells were collected by centrifugation as above and resuspended in Neurobasal containing $2 \%$ B27 supplement, $0.5 \mathrm{~mm}$ glutamine, $100 \mathrm{IU} / \mathrm{ml}$ penicillin, $100 \mu \mathrm{g} / \mathrm{ml}$ streptomycin, and $10 \mathrm{ng} / \mathrm{ml} \mathrm{FGF-2.} \mathrm{Cells}\left(1 \times 10^{6}\right)$ were plated on $10 \mathrm{~cm}$ plastic tissue culture plates precoated with $0.01 \%$ poly-L-lysine and $1 \mu \mathrm{g} / \mathrm{ml}$ fibronectin. The medium was changed every 3-4 d. Cells were passaged at $50-75 \%$ confluence by incubating them briefly in warm PBS and scraping them with a cell scraper.

Immunocytochemistry. For immunofluorescence double-staining the cells were cultured on Lab-Tek slides (Nunc, Naperville, IL) that had been precoated with $0.01 \%$ poly-L-lysine and $1 \mu \mathrm{g} / \mathrm{ml}$ fibronectin. The cells were fixed with $4 \%$ paraformaldehyde in PBS for $10 \mathrm{~min}$ and permeabilized with $0.5 \%$ Triton X-100 in PBS for 5 min; then they were blocked in 5\% bovine serum albumin in Tris-buffered saline (TBS) for 10 min and incubated with primary antibodies at $37^{\circ} \mathrm{C}$ overnight, followed by Oregon Green-conjugated anti-mouse antibody and Texas Redconjugated anti-rabbit antibody.

For dephosphorylation, fixed cells were treated after the blocking step with $256 \mathrm{U} / \mathrm{ml}$ alkaline phosphatase (Sigma) at $37^{\circ} \mathrm{C}$ overnight. After incubation the cells were washed with warm TBS, reblocked with $5 \%$ bovine serum albumin in TBS for $5 \mathrm{~min}$, and incubated with primary and secondary antibodies as above.

Preparation of cell samples and rat brain homogenate. Cells were cultured up to $\sim 70-90 \%$ confluence in 10 -cm-diameter dishes. For harvesting, the culture medium first was changed to cold $\left(4^{\circ} \mathrm{C}\right) \mathrm{PBS}$, and the cells were collected immediately with a cell scraper and centrifuged at $800 \times$ $g$ at $4^{\circ} \mathrm{C}$ for $5 \mathrm{~min}$. In most cases the resulting cell pellets were lysed in $0.4 \%$ SDS and $0.4 \% \beta$-mercaptoethanol (BME) solution, immediately probe-sonicated, and boiled for $5 \mathrm{~min}$. The lysates were aliquoted and stored at $-85^{\circ} \mathrm{C}$ until use. For detection of tau isoforms and GSK-3 assay, the cells were lysed on ice for $30 \mathrm{~min}$ in lysis buffer [ $50 \mathrm{~mm}$ Tris, $\mathrm{pH} 8.2$, for tau isoform analysis and $\mathrm{pH} 7.4$ for GSK-3 assay; $0.1 \%$ Triton X-100; $20 \mathrm{~mm} \mathrm{NaCl}$; $1 \mathrm{~mm}$ phenylmethane-sulfonylfluoride (PMSF); and (in $\mu \mathrm{g} / \mathrm{ml}) 5$ leupeptin, 5 aprotinin, 2 pepstatin A, and 50 phosphoramidon], and centrifuged at $200,000 \times g$ for $30 \mathrm{~min}$. The resulting extracts were aliquoted and stored as above. The protein concentrations were determined by the modified Lowry method of Bensadoun and Weinstein (1976).

For the detection of tau isoforms, cell extracts $(15 \mu \mathrm{g})$ from adult and fetal progenitor cells and from the cortex of a 3-month-old rat were mixed with alkaline phosphatase in the proportion of $2 \mu \mathrm{g}$ of sample per $1 \mathrm{U}$ of alkaline phosphatase, adjusted to $156-2000 \mathrm{U} / \mathrm{ml}$ with lysis buffer, and incubated at $37^{\circ} \mathrm{C}$ overnight. The incubation was stopped by adding the appropriate amount of SDS-BME solution and immediate boiling it for $5 \mathrm{~min}$.

Treatment with growth factors. Cells that had been cultured with 10 $\mathrm{ng} / \mathrm{ml} \mathrm{FGF-2} \mathrm{in} \mathrm{10-cm-diameter} \mathrm{dishes} \mathrm{were} \mathrm{used} \mathrm{to} \mathrm{study} \mathrm{the} \mathrm{effects} \mathrm{of}$ FGF-2. On the starting day (experimental day 0), the medium was changed to new Neurobasal A/B27 (or Neurobasal/B27 for fetal stem cells) containing various concentrations of FGF-2. The medium was changed on experimental days 2,4 , and 6 with the same medium, and the cells were lysed on experimental day 7 .

For transformation to astrocytes the cells were cultured with $10 \mathrm{ng} / \mathrm{ml}$ FGF-2 on Lab-Tek slides. On experimental day 0 the medium was changed to new Neurobasal A/B27 containing both $10 \mathrm{ng} / \mathrm{ml}$ ciliary neurotrophic factor (CNTF; Sigma) and FGF-2. The next day (day 1) the cells received fresh medium containing either $10 \mathrm{ng} / \mathrm{ml} \mathrm{CNTF}$ alone or CNTF with $20 \mathrm{ng} / \mathrm{ml} \mathrm{FGF-2.} \mathrm{Further} \mathrm{medium} \mathrm{changes} \mathrm{were} \mathrm{done} \mathrm{on}$ experimental days 3,5 , and 7 , and the cells were fixed on experimental day 8 and double-stained as described above.

Radio immunoblots. Indicated amounts of protein samples were electrophoresed on at least triplicate SDS-polyacrylamide gels $(8 \times 6 \times 0.75$ $\mathrm{cm} ; 6,10$, or $5-10 \%$ acrylamide), transferred to Immobilon membranes (Millipore, Bedford, MA), and probed with primary antibodies. To assay the degree of phosphorylation at the Tau-1 site, we treated the membranes with or without alkaline phosphatase $(196 \mathrm{U} / \mathrm{ml})$ at $37^{\circ} \mathrm{C}$ for $8 \mathrm{hr}$ in dephosphorylation buffer [containing (in mM) 50 Tris, $\mathrm{pH} 8.2,2$ $\mathrm{MgCl}_{2}$, and 1 PMSF plus (in $\mu \mathrm{g} / \mathrm{ml}$ ) 5 leupeptin, 5 aprotinin, 2 pepstatin $\mathrm{A}$, and 50 phosphoramidon] before the application of Tau- 1 . Bound antibodies were probed with ${ }^{125} \mathrm{I}$-conjugated anti-mouse or anti-rabbit IgG. The radio immunoblots were scanned with a Fuji BAS 1500 Bio Image analyzer (Raytest USA, Wilmington, DE). Images were processed with the Tina software, and the strength of immunostaining was expressed as pixels per square length (PSL). Tau levels (micrograms of 
A
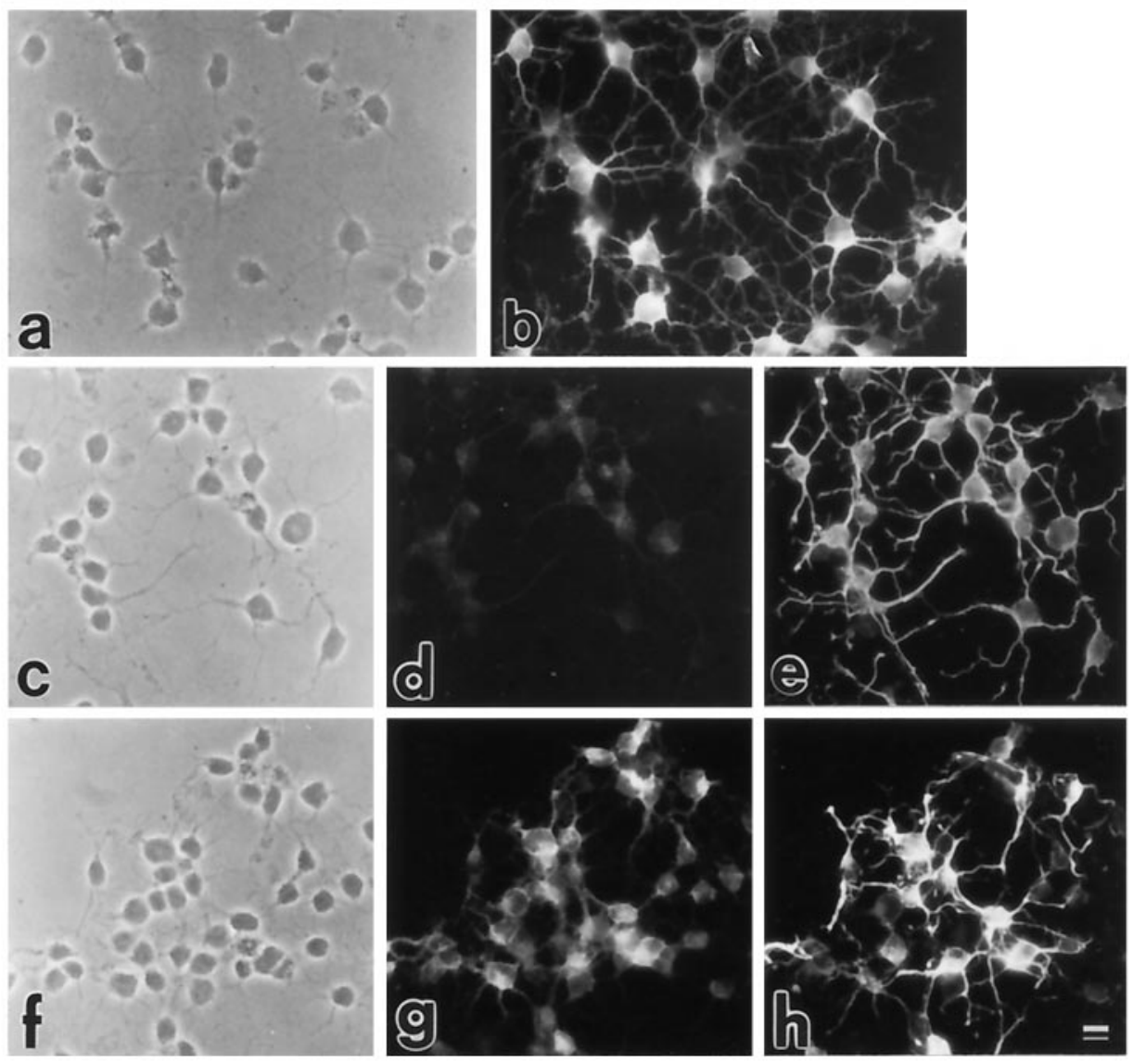

B

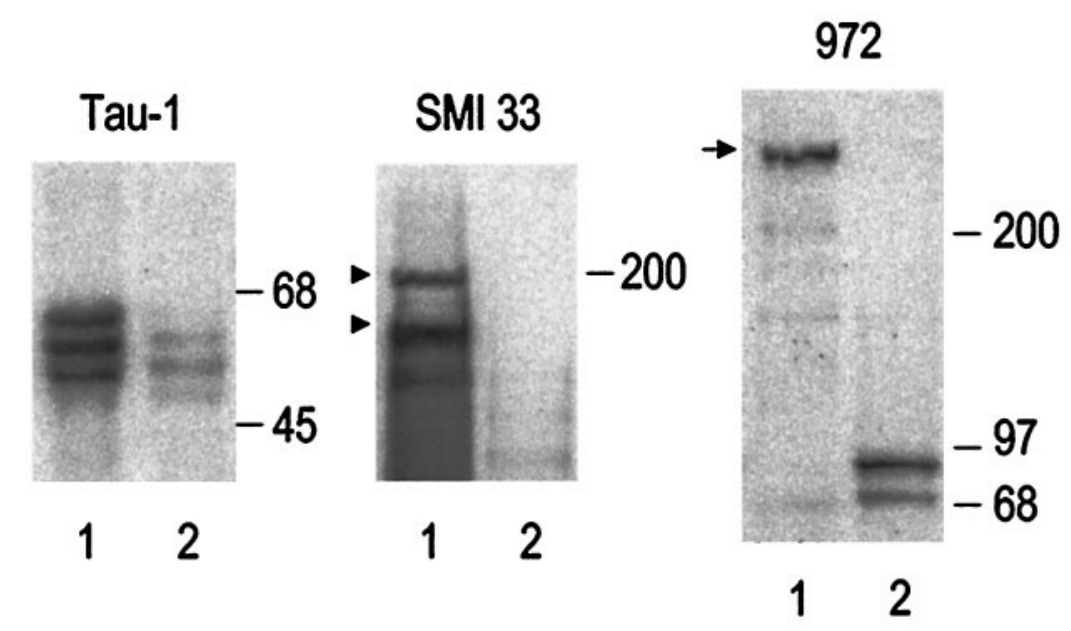

Figure 1. Proliferating adult hippocampal progenitor cells express not only nestin and MAP-2C but also tau, with the Tau-1 site phosphorylated. $A$, Expression of tau and nestin in proliferating adult hippocampal progenitor cells. Adult hippocampal progenitor cells (passage 7) were cultured with 10 $\mathrm{ng} / \mathrm{ml} \mathrm{FGF-2} \mathrm{on} \mathrm{Lab-Tek} \mathrm{slides} \mathrm{and} \mathrm{stained} \mathrm{as} \mathrm{described} \mathrm{in} \mathrm{Materials} \mathrm{and} \mathrm{Methods.} a$, Phase contrast; $b$, anti-tau serum R134d. $c-h$, Cells were double-stained with Tau-1 and nestin (\#133) antibodies without $(c-e)$ and with $(f-h)$ alkaline phosphatase pretreatment; $(c, f)$ phase contrast; $(d, g)$ Tau-1; $(e, h)$ nestin (\#133). Note that most adult progenitor cells were tau-positive. After alkaline phosphatase treatment most of the nestin-positive cells also became Tau-1-positive, indicating that tau in adult progenitor cells is phosphorylated at the Tau-1 site. Scale bar, $10 \mu \mathrm{m}$. $B$, Western blot analysis of lysates from adult progenitor cells and rat brain. Lysates $(15 \mu \mathrm{g})$ from a 3-month-old rat brain tissue (1) and adult hippocampal progenitor cells (2) were applied on 5-10\% SDS-polyacrylamide gels. Transferred membranes were pretreated with alkaline phosphatase and analyzed with antibodies Tau-1 (anti-dephosphorylated tau), SMI 33 (anti-dephosphorylated neurofilament H and M), and 972 (anti-dephosphorylated MAP-2A-C). Note that adult progenitor cells express tau and MAP-2C, but not the high-molecular-weight MAP-2 (arrow) and neurofilament $\mathrm{H}$ and M (arrowheads). 


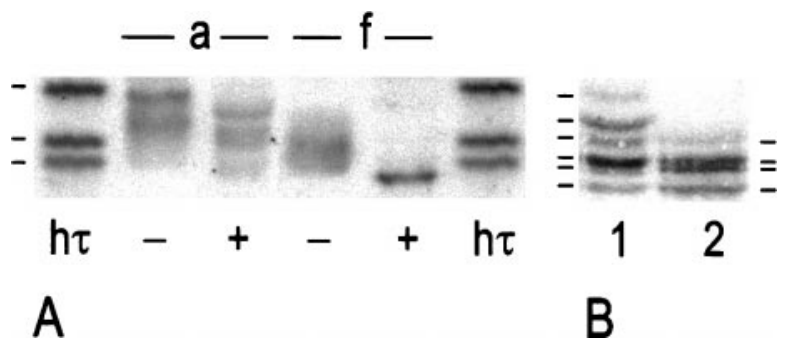

Figure 2. Adult hippocampal progenitor cells express adult isoforms of tau, and fetal cells express only the fetal tau isoform. $A$, Tau isoforms expressed by adult and fetal hippocampal progenitor cells. Extracts (15 $\mu \mathrm{g})$ from adult $(-a-)$ and fetal $(-f-)$ progenitor cells were incubated in vitro with $(+)$ or without $(-)$ alkaline phosphatase and analyzed by Western blots with phospho-independent polyclonal antibody 92e. $h \tau$, Recombinant human tau 39, 24, and 23 (10 ng each). Bars indicate their apparent molecular weights (from top to bottom) of 62,52 , and $48 \mathrm{kDa}$, respectively. Note that, after treatment with alkaline phosphatase in vitro, tau from fetal cells was resolved into a single band, but tau from adult cells still showed several major bands. $B$, Comparison of the tau isoform profiles of adult hippocampal progenitor cells and rat brain tissue. Extracts $(15 \mu \mathrm{g})$ from a 3-month-old rat (1) and adult hippocampal progenitor cells (2) were incubated in vitro with alkaline phosphatase, applied on a $6 \%$ gel, and analyzed with the Tau-1 antibody. Bars left and right indicate the apparent molecular weights of tau isoforms (from top to bottom) of 61,58 (only on left), 53, 50,46, and $43 \mathrm{kDa}$, respectively. The $58 \mathrm{kDa}$ tau isoform in the progenitor cells could be observed only if the membrane was overexposed (data not shown).

tau/mg total protein) were determined by comparing the PSLs of known amounts of recombinant tau and of the taus in total cell lysates in the blots treated with alkaline phosphatase and stained with Tau-1. Phosphorylation at the Tau-1 epitope (percentage of phosphorylation) was calculated by the following formula: [PSL of Tau-1 in alkaline phosphatase-treated blot (total tau) - PSL of Tau-1 in the untreated blot (tau not phosphorylated at the Tau-1 site)]/PSL of Tau-1 in alkaline phosphatase-treated blot (total tau) $\times 100$.

GSK-3 assay. Activities of GSK-3 were determined as described previously (Pei et al., 1997). Aliquots of $50 \mu \mathrm{g}$ of cell extract protein were diluted to $250 \mu \mathrm{l}$ with lysis buffer and mixed with $250 \mu \mathrm{l}$ of TBS, $300 \mathrm{~mm}$ $\mathrm{NaCl}$, and $1 \mathrm{~mm}$ PMSF with or without $2 \mu \mathrm{l}$ of anti-GSK-3 serum R133. After incubation at $4^{\circ} \mathrm{C}$ for $8 \mathrm{hr}, 20 \mu \mathrm{l}$ of immobilized G-protein (Pierce, Rockford, IL) was added to the mixtures, which were incubated further at $4^{\circ} \mathrm{C}$ for $2 \mathrm{hr}$ and then centrifuged. The precipitates were washed three times and suspended in $50 \mu \mathrm{l}$ of $50 \mathrm{~mm}$ Tris, $\mathrm{pH} 7.4$, containing $10 \mathrm{~mm}$ $\mathrm{MgCl}_{2}$ and $1 \mathrm{~mm}$ PMSF. Equal amounts $(10 \mu \mathrm{l})$ of precipitate suspension, $800 \mu \mathrm{M}\left[\gamma_{-}{ }^{32} \mathrm{P}\right]$ ATP, $0.4 \mathrm{mg} / \mathrm{ml}$ phosphoglycogen synthase peptide 2 (UBI, Lake Placid, NY), and $120 \mathrm{~mm}$ Tris, $\mathrm{pH}$ 7.4, containing (in mM) 40 $\mathrm{MgCl}_{2}, 40 \mathrm{NaF}, 4 \mathrm{Na}_{3} \mathrm{VO}_{4}, 8 \mathrm{EGTA}$, and $40 \mathrm{BME}$ were mixed and incubated at $30^{\circ} \mathrm{C}$ for $30 \mathrm{~min}$. All assays were performed in triplicate. Reactions were stopped with $40 \mu \mathrm{l}$ of $300 \mathrm{~mm} o$-phosphoric acid, and the mixtures were applied to phosphocellulose units (Pierce). The filters were washed three times with $75 \mathrm{~mm}$ phosphoric acid, dried, and counted. For negative control the precipitates that had been incubated without antibody were used. GSK-3 activity was obtained by subtracting the counts in the absence of antibody from the counts in the presence of antibody.

\section{RESULTS}

\section{Adult hippocampal progenitor cell cultures express nestin, MAP-2C, and phosphorylated tau}

Hippocampal cells were isolated from adult brain and cultured with $5 \mathrm{ng} / \mathrm{ml} \mathrm{FGF-2} \mathrm{for} \mathrm{the} \mathrm{first} 3$ months. In the first few weeks the cultures were heterogeneous, containing one major type of cells with small round cell bodies and multiple branched, thin processes. A change of FGF-2 from 5 to $10 \mathrm{ng} / \mathrm{ml}$ dramatically increased the speed of proliferation of these cells.

After the fifth passage, almost all of the cells immunocytochemically stained intensely with polyclonal antibody $134 \mathrm{~d}$ for tau, which recognizes tau in a phosphorylation-independent manner (Fig. 1 $A a, A b)$. In contrast, these cells were stained only poorly with antibody Tau-1, which recognizes only tau that is not phosphorylated at the Tau-1 epitope (Fig. $1 A c, A d$ ). However, when the fixed cells were dephosphorylated with alkaline phosphatase before the application of Tau-1 antibody, the staining pattern changed dramatically (Fig. $1 A f, A g$ ) in that almost all of the cells were immunostained intensely. Both Tau-1 and 134d antibodies stained cell bodies and processes, but not the nuclei, suggesting that tau in these cells is mostly cytosolic. Most cells also were stained with antibody 972 to dephosphorylated MAP2A-C (data not shown), whereas only a rare cell was stained with GFAP antibodies (data not shown). Almost all of the cells also were stained with monoclonal (data not shown) and polyclonal antibodies to nestin (Fig. 1 $A e, A h$ ), a marker for immature neural cells. In some instances the nestin staining increased after dephosphorylation (Fig. 1Ah). Presently, it is not known whether this treatment nonspecifically increased the antibody accessibility to nestin by unmasking it or whether nestin antibody \#130 is somewhat phospho-dependent.

Western blot analysis of the cell lysates with monoclonal antibody Tau-1 after dephosphorylation of the blot revealed several immunopositive bands in the 48-62 $\mathrm{kDa}$ area but with slightly different mobilities from the major tau bands in rat brain (Fig. $1 B$, Tau-1). In contrast to rat brain homogenate, which also contained the high-molecular-weight isoforms of MAP-2 and the $\mathrm{H}$ and $\mathrm{M}$ neurofilament subunits, in the cell lysates only MAP-2C $(\sim 70$ $\mathrm{kDa}$ ) and a band of $\sim 90 \mathrm{kDa}$, most probably a MAP-2Cderivative variant (Kalcheva et al., 1997), but not MAP-2A and MAP-2B, were detected with antibody 972 (Fig. 1B, 972). No neurofilament polypeptides were labeled with antibody SMI 33 in the cell lysates (Fig. 1B, SMI 33). These data demonstrate clearly that the cells we cultured were morphologically and immunocytochemically indistinguishable from adult hippocampal progenitor cells or the stem cells described previously (Gage et al., 1995; Johe et al., 1996; Palmer et al., 1997); these cells will be called "progenitor cells" below.

\section{Expression of tau isoforms in adult and fetal hippocampal progenitor cells}

To study the isoform composition of tau in adult and fetal progenitor cells, we compared polypeptide patterns of tau in cell extracts by Western blots developed with phospho-independent polyclonal antibody 92e. Cell extracts were incubated in vitro with or without alkaline phosphatase before application on the gel (Fig. 2A). Without dephosphorylation, tau in the cell extracts from both adult and fetal progenitor cells showed several immunoreactive bands ranging from 48 to $62 \mathrm{kDa}$. However, on in vitro dephosphorylation, tau from adult progenitor cells was resolved into three major distinct bands. In contrast, tau from fetal progenitor cells showed only a single band of $\sim 43 \mathrm{kDa}$, suggesting that adult hippocampal progenitor cells express adult isoforms of tau, whereas fetal hippocampal progenitor cells express only the fetal tau isoform (Fig. 2A). On Western blots that used 6\% gradient gels and Tau-1 antibody, tau from the adult progenitor cells was resolved into five isoforms but in different ratios from those seen in rat brain (Fig. $2 B$ ). Tau from adult rat brain was resolved into six bands of $61,58,53,50,46$, and $43 \mathrm{kDa}$. In contrast, tau from adult progenitor cells resolved into four major polypeptides of $53,50,46$, and $43 \mathrm{kDa}$ and a weakly labeled polypeptide of $58 \mathrm{kDa}$, which was visible only when the ${ }^{125} \mathrm{I}$ blot was overexposed. An identical Tau-1-immunoreactive band pat- 

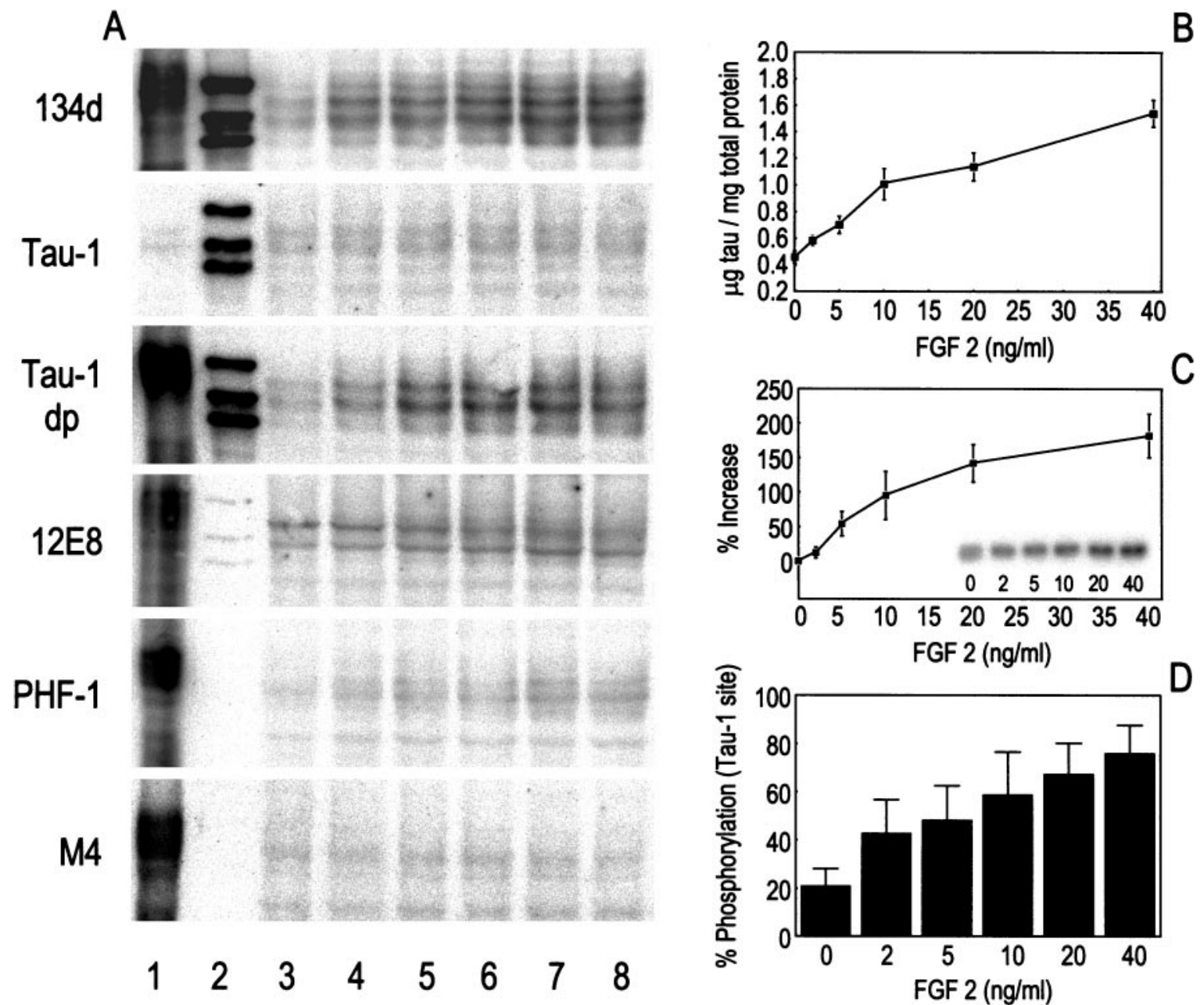

B
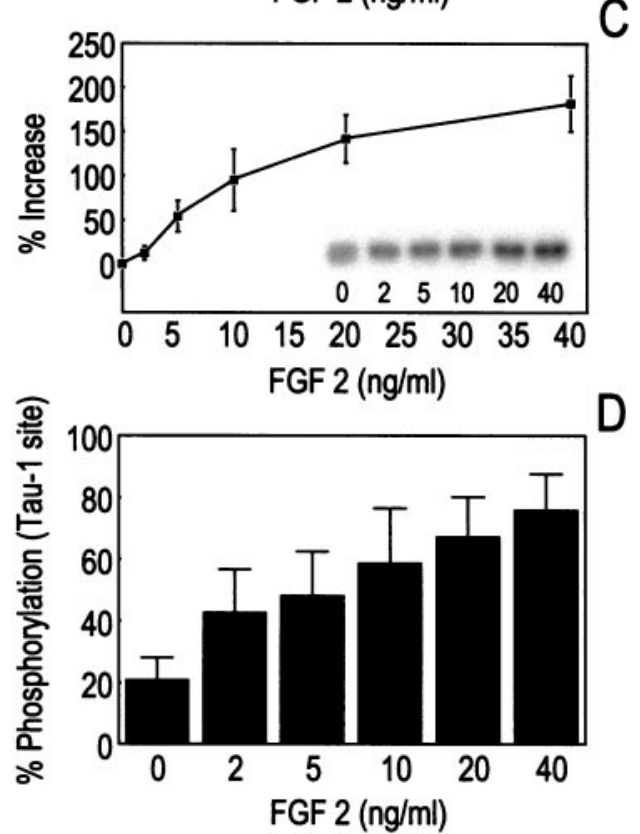

Figure 3. FGF-2 increases the tau and tubulin expressions and the degree of tau phosphorylation at the Tau-1 site in adult hippocampal progenitor cells. $A$, Western blot analysis of cell lysates from adult hippocampal progenitor cells cultured with increasing concentrations of FGF-2. Adult progenitor cells (passage 8) cultured with $0,2,5,10,20$, and $40 \mathrm{ng} / \mathrm{ml}$ of FGF-2 for $7 \mathrm{~d}$ were lysed and analyzed with phosphorylation-independent antibody $134 \mathrm{~d}$ and with phosphorylation-dependent antibodies Tau-1 without (Tau-1) or with (Tau-1 dp) alkaline phosphatase treatment on the membranes, 12E8, PHF-1, and M4. Lane 1, AD P-tau, $3 \mu \mathrm{g}$; lane 2, mixture of recombinant human tau 23, 24, and 39, $10 \mathrm{ng}$ each. Lanes 3-8, Cell lysates, $12.5 \mu \mathrm{g}$, from the cultures with different concentrations of FGF-2: lane 3, $0 \mathrm{ng} / \mathrm{ml}$; lane 4, $2 \mathrm{ng} / \mathrm{ml}$; lane 5, $5 \mathrm{ng} / \mathrm{ml}$; lane 6, $10 \mathrm{ng} / \mathrm{ml}$; lane 7, $20 \mathrm{ng} / \mathrm{ml}$; lane 8, 40 ng/ml. B, Tau levels increase, depending on the FGF-2 concentrations. Tau levels in adult hippocampal progenitor cells (passage 8) were determined from the radio immunoblots as described in Materials and Methods $(n=3)$. Absolute tau amounts (micrograms of tau per milligram total protein) were derived by using recombinant human tau as a standard. Similar results also were obtained with adult progenitor cells that had been passaged five times. $C$, Tubulin levels increase with increased FGF-2 concentration. Cell lysates $(6 \mu \mathrm{g})$ were analyzed by Western blots with tubulin monoclonal antibody DM1A (inset). The percentage of increase in immunoreactivity was calculated on the basis of the value of FGF- 2 at $0 \mathrm{ng} / \mathrm{ml}(n=3)$, which was taken as $0 \%$. $D$, The phosphorylation of tau at the Tau-1 site increases with increased FGF-2 concentration. The degree of phosphorylation at the Tau-1 site was determined from the Western blots as described in Materials and Methods $(n=3)$. Note that FGF-2 had a strong effect on the phosphorylation of tau at the Tau-1 site in adult progenitor cells.

tern was observed even after incubation with several-folds of alkaline phosphatase (1000-2000 U/ml; data not shown). These data show that undifferentiated proliferating adult hippocampal progenitor cells do express adult isoforms of tau, but the ratio at which the isoforms are expressed is different from that of rat cerebrum.

\section{Regulation of expression and phosphorylation of tau by FGF-2}

Adult progenitor cells

To determine the effect of FGF-2 on tau expression, we incubated cells with increasing concentrations of FGF-2, ranging from 0 to $40 \mathrm{ng} / \mathrm{ml}$ for $7 \mathrm{~d}$, and we determined the levels of tau in the cell lysates by $\left[{ }^{125} \mathrm{I}\right]$ Western blots as described in Materials and Methods. Using phospho-independent tau antibody 134d, we found that
FGF-2 markedly increased, in a concentration-dependent manner, the level of total tau expression (Fig. $3 A, B$ ). This effect also was observed in Tau-1 blots treated with alkaline phosphatase. In cultures without FGF-2, the tau level was $\sim 0.45 \mu \mathrm{g} / \mathrm{mg}$ of total protein. This amount increased with an increase in FGF- 2 concentration and reached $\sim 1.5 \mu \mathrm{g} / \mathrm{mg}$ at $40 \mathrm{ng} / \mathrm{ml}$ of FGF-2 concentration (Fig. 3B). Furthermore, in addition to the FGF-2-dependent increase of total tau, tubulin levels also increased (Fig. $3 C$ ).

As shown in Figure 1 by immunocytochemistry, tau in adult progenitor cells is phosphorylated at the Tau- 1 site. This also was confirmed by immunoblot analysis (Fig. $3 A$ ). Radio immunoblot assays demonstrated that the degree of phosphorylation at the Tau-1 site also is regulated strongly by the concentration of FGF-2 (Fig. 3D). In FGF-2-depleted cultures the phosphorylation 

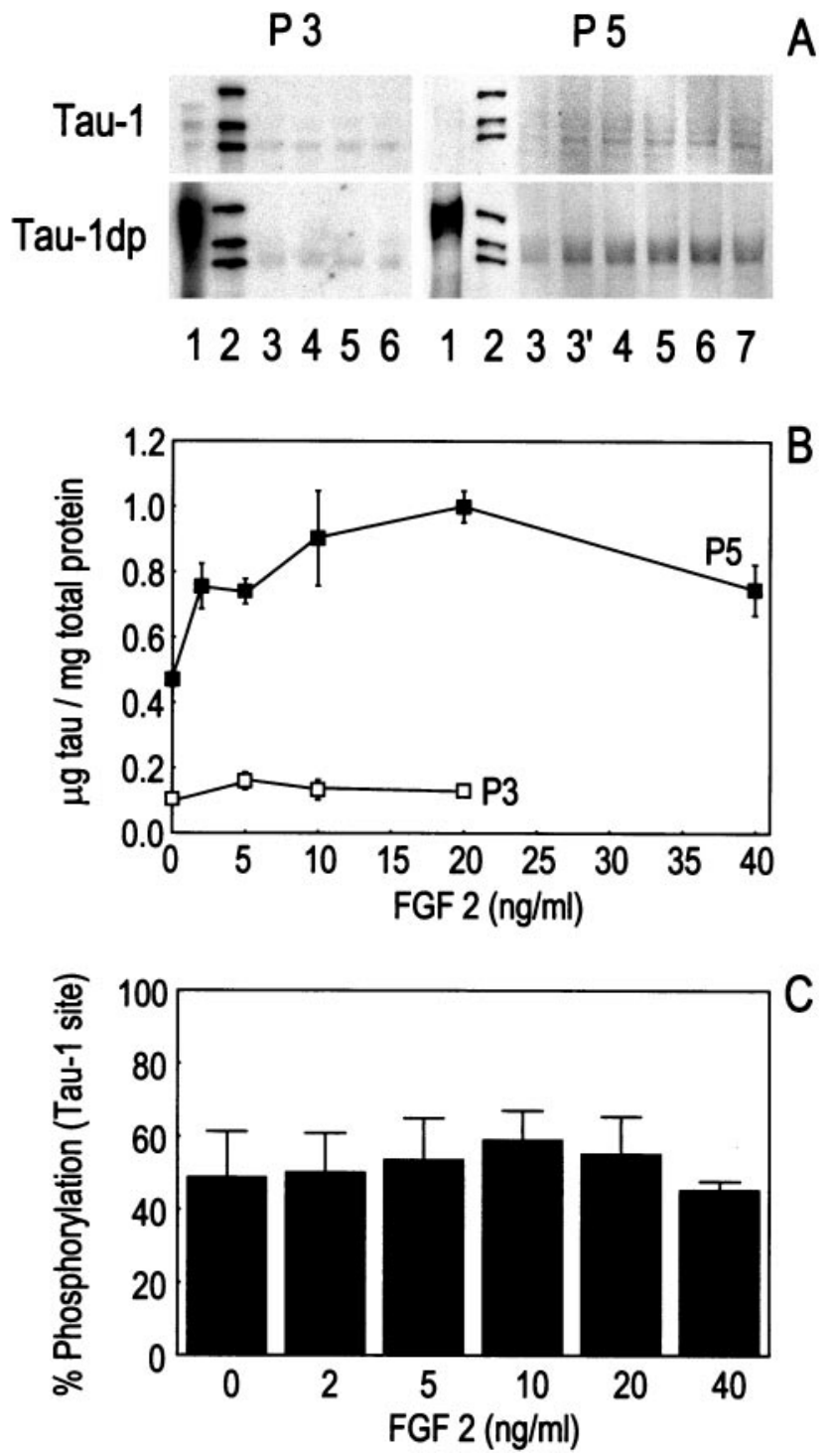

Figure 4. In fetal hippocampal progenitor cells, FGF-2 increases the expression of tau only in cultures of higher passages but has no effect on the phosphorylation at the Tau- 1 site. $A$, Western blot analysis of cell lysates from fetal hippocampal progenitor cells. Fetal hippocampal progenitor cells, passage $3(P 3)$ and passage $5(P 5)$, cultured with increasing concentrations of FGF-2 for $7 \mathrm{~d}$ were lysed and analyzed with Tau-1 without (Tau-1) or with (Tau-1 dp) alkaline phosphatase treatment on the membranes. Lane 1, AD P-tau, $3 \mu \mathrm{g}$; lane 2, mixture of recombinant human tau 23, 24, and 39, $10 \mathrm{ng}$ each. Lanes 3-7, Cell lysates $(12.5 \mu \mathrm{g})$ from the cultures with increasing concentrations of FGF-2: lane 3, 0 $\mathrm{ng} / \mathrm{ml}$; lane 3', $2 \mathrm{ng} / \mathrm{ml}$; lane 4, $5 \mathrm{ng} / \mathrm{ml}$; lane $5,10 \mathrm{ng} / \mathrm{ml}$; lane $6,20 \mathrm{ng} / \mathrm{ml}$; lane 7, $40 \mathrm{ng} / \mathrm{ml}$. Note that fetal progenitor cells in P3 cultures expressed fetal tau very weakly, and FGF-2 had no effect on its expression or phosphorylation. In contrast, the cells in P5 cultures expressed tau abundantly, and FGF-2 increased its expression. $B$, Tau levels in fetal hippocampal progenitor cells increase with increased concentration of FGF-2 only in later passages. Tau levels were analyzed from the Western blots and expressed by using the same methods as for Figure $3 B$. Tau levels increased 5- to 10-fold in P5 cultures as compared with P3 cultures. Moreover, FGF-2 altered tau expression only in P5 culture. $C$, Degree of phosphorylation at the Tau- 1 site in fetal hippocampal progenitor cells is independent of the concentration of FGF-2. The degree of phosphorylation in the P5 cultures was determined as described in Materials and Methods. Similar results also were obtained in P3 cultures (data not shown). Note that FGF-2 had no effect on tau phosphorylation at the Tau-1 site. at the Tau-1 site was only $\sim 20 \%$ but increased to close to $80 \%$ at an FGF-2 concentration of $40 \mathrm{ng} / \mathrm{ml}$. A small increase in phosphorylation also was seen at the $12 \mathrm{E} 8$ and PHF-1 sites concurrent with increased FGF-2 (Fig. $3 A$ ). However, this increase in phosphorylation was not observed when normalized against total tau (as determined with Tau-1 after dephosphorylation), suggesting that the increased tau is in the form of the protein phosphorylated at the $12 \mathrm{E} 8$ and PHF-1 sites. Antibody M4 recognized tau weakly with the immunostaining, even slightly decreasing with increasing tau concentrations. Thus it is indicated that this site is not phosphorylated significantly in adult hippocampal progenitor cells as a response to FGF-2 (Fig. $3 A$ ).

\section{Fetal progenitor cells}

The effect of FGF-2 on the expression and the phosphorylation of tau also was investigated in progenitor cells from fetal rat hippocampus. During the first three passages the total tau appeared to decrease in the fetal progenitor cells (data not shown), as described previously (Sah et al., 1997). The tau level in the cells from the third passage was $\sim 0.1 \mu \mathrm{g} / \mathrm{mg}$ of total protein, and FGF-2 had no effect on the total tau expression or phosphorylation at the Tau-1 site (Fig. 4A,B). However, in the fifth passage even tau from cells that had been grown for 1 week in FGF-2depleted medium was increased fivefold to approximately the same level as the similarly treated adult progenitor cells (compare Figs. $3 B, 4 B$ ). The addition of FGF-2 to these cultures resulted in an increase in the tau level, but this increase was only one-half of that seen in the adult cells, even at $20 \mathrm{ng}$ FGF-2/ml, the maximal point of increase. At $40 \mathrm{ng} / \mathrm{ml}$ of FGF-2 the tau content decreased. The reason for this negative switch is not understood at present. A possibility is that the inhibition of tau expression beyond a certain maximal point represents a regulatory mechanism by the fetal cells. In contrast to adult cells, $50 \%$ of tau already was phosphorylated at the Tau-1 site in the FGF-2depleted fetal cells, and the addition of FGF-2 did not have any effect on Tau-1 phosphorylation (Fig. 4C). Thus, the regulation of expression and phosphorylation of tau by FGF-2 between adult and fetal hippocampal progenitor cells was different.

Even cultures grown for up to 3 months with multiple passages expressed mostly fetal tau, suggesting that factors other than FGF-2 are required to induce adult isoforms of tau in fetal hippocampal progenitor cells.

\section{Differentiated astrocytes}

To elucidate whether the effect of FGF-2 on tau is limited to undifferentiated progenitor cells or also might extend to cells differentiated into astrocytes, we stimulated progenitor cells with $10 \mathrm{ng} / \mathrm{ml}$ of CNTF with or without the addition of FGF-2 (20 $\mathrm{ng} / \mathrm{ml}$ ), as described in Materials and Methods. CNTF converts adult neural progenitor cells to astrocytes (Johe et al., 1996). After stimulation for $8 \mathrm{~d}$ the cells were double-stained with monoclonal antibody to GFAP and polyclonal tau antibody $134 \mathrm{~d}$. In cultures stimulated with only CNTF on alternate days, $\sim 30-$ $40 \%$ of the cells were GFAP-positive. The GFAP-positive cells contained no or only very low tau immunoreactivity (Fig. 5b,c). In cultures that were stimulated simultaneously with CNTF and FGF-2, the same proportion of cells was stained with GFAP. However, most of the GFAP-positive astrocytes also were strongly tau-positive, at approximately the same intensity as in undifferentiated progenitor cells (Fig. $5 e, f$ ). Immunocytochemistry with Tau-1 antibody with or without alkaline phosphatase treatment showed that, as in the undifferentiated adult progenitor 

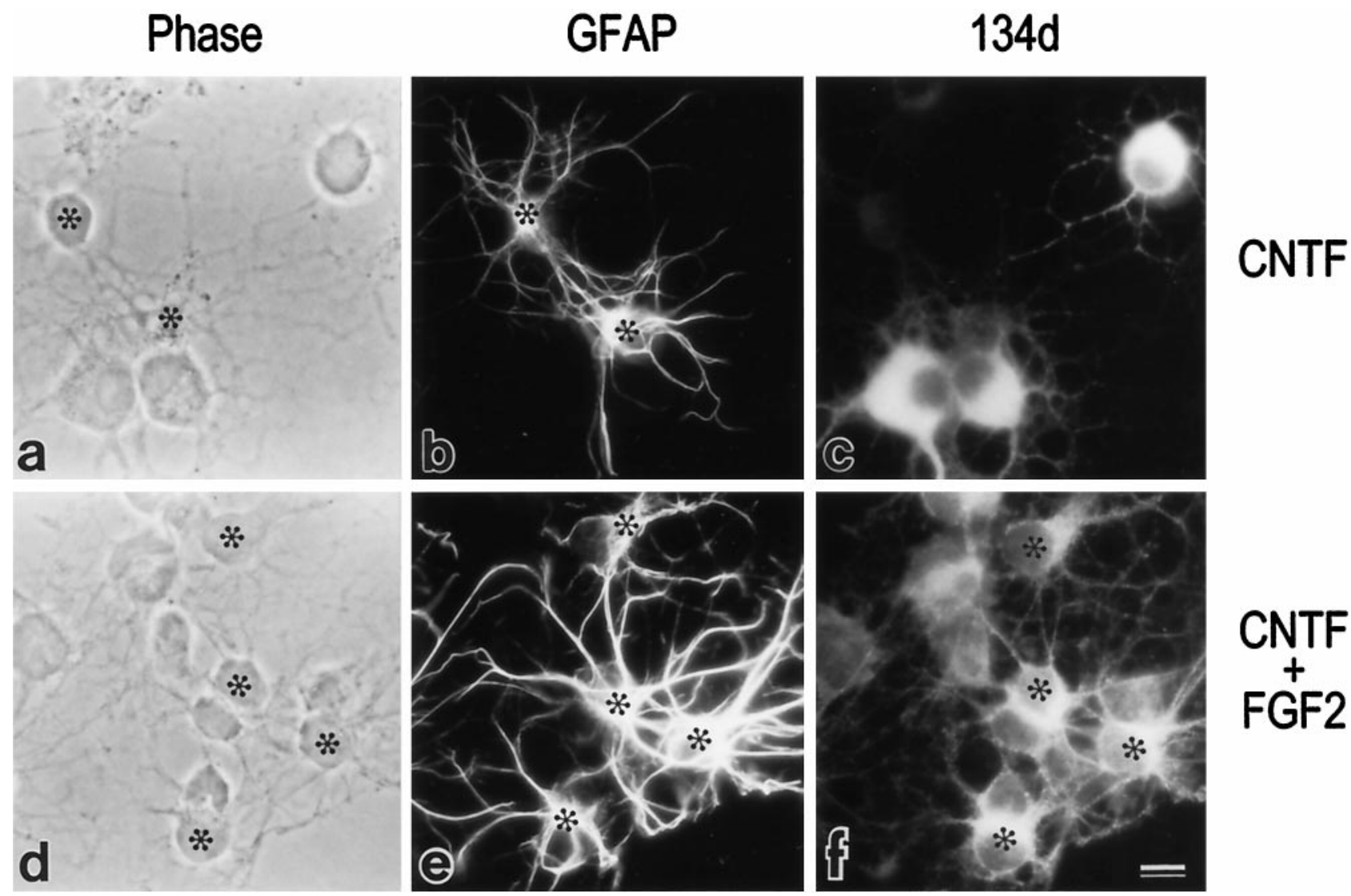

Figure 5. Effect of FGF-2 on the expression of tau in differentiated astrocytes. Adult hippocampal progenitor cells cultured with $10 \mathrm{ng} / \mathrm{ml} \mathrm{CNTF}$ alone $(a-c)$ or, in addition, with $20 \mathrm{ng} / \mathrm{ml} \mathrm{FGF-2}(d-f)$ for $8 \mathrm{~d}$ as in Materials and Methods were double-stained with mono-GFAP and 134d. $a$, $d$, Phase contrast; $b, e$, mono-GFAP; $c, f, 134 \mathrm{~d}$. In the cultures stimulated with CNTF alone, differentiated astrocytes were tau-negative $(c)$ or very weakly tau-positive (data not shown). In contrast, in cultures stimulated with both CNTF and FGF-2, most astrocytes expressed tau strongly with the same intensity as undifferentiated progenitor cells. Asterisks show differentiated astrocytes. The tau-positive cells in $c$ and $f$ most probably represent undifferentiated progenitor cells (GFAP-negative). Scale bar, $10 \mu \mathrm{m}$.

cells, the Tau-1 site was hyperphosphorylated (data not shown). These findings indicate that FGF-2 affects tau expression and phosphorylation even in adult differentiated astrocytes.

\section{Mechanism of the phosphorylation of tau by FGF-2 in adult progenitor cells}

To date, MAPK, GSK-3, and Cdk-5 are the three major candidate kinases that have been reported to induce tau phosphorylation at the Tau-1 site in vitro (Drewes et al., 1992; Hanger et al., 1992; Vulliet et al., 1992; Singh et al., 1995b). Therefore, to identify the protein kinase(s) that might be involved in the FGF2-induced tau hyperphosphorylation in adult progenitor cells, we examined the effect of inhibitors specific to the above kinases. After the indicated periods of incubation with each kinase inhibitor and $10 \mathrm{ng} / \mathrm{ml} \mathrm{FGF-2,} \mathrm{the} \mathrm{cells} \mathrm{were} \mathrm{lysed} \mathrm{and} \mathrm{analyzed} \mathrm{with}$ Tau-1 antibody on Western blots that had been treated or untreated with alkaline phosphatase (Fig. 6A). PD 98059, which inhibits the activation of MAPK/MAPK kinase (Alessi et al., 1995), and butyrolactone I, which inhibits the activities of cdks (Hosoi et al., 1995), failed to inhibit the phosphorylation of tau induced by FGF-2 (Fig. 6A). However, lithium, which inhibits GSK-3 activity (Klein and Melton, 1996), inhibited the phosphorylation of tau and resulted in a mobility shift of tau bands (see Fig. $6 \mathrm{~A}$; compare lane 2 with lanes $1,3,4)$. For further confirmation the cells were treated at different concentrations of $\mathrm{LiCl}$ for $6 \mathrm{hr}$, and the percentage of phosphorylation was determined as de- scribed in Materials and Methods (Fig. 6B). The degree of phosphorylation at the Tau-1 site was decreased by increasing concentrations of $\mathrm{LiCl}$ in a dose-dependent manner, suggesting that GSK-3 is the kinase involved in the FGF-2 signaling pathways.

To confirm the involvement of GSK-3 in the FGF-2-mediated hyperphosphorylation of tau, we assayed the GSK-3 activity, using phosphoglycogen synthase peptide 2 as the specific substrate. GSK-3 was immunoprecipitated from the cell extracts, and its kinase activity was assayed. As expected, FGF-2 increased GSK-3 activity in a dose-dependent manner (Fig. 6C), again supporting the concept that FGF-2 induces tau phosphorylation by activating GSK-3.

\section{DISCUSSION}

The nature of the extracellular signal that regulates the expression and phosphorylation of tau is not understood. The present study shows for the first time that (1) neural proliferating progenitor cells from adult rat brain stably express adult isoforms of tau, (2) that the expression and the phosphorylation at the Tau- 1 site of the adult tau isoforms are regulated by FGF-2, (3) that the kinase responsible for the FGF-2-mediated tau phosphorylation is GSK-3, and (4) that FGF-2 induces expression and phosphorylation of tau in differentiated astrocytes. In contrast, fetal progenitor cells express mostly fetal tau, and FGF-2 regulates only its 
A

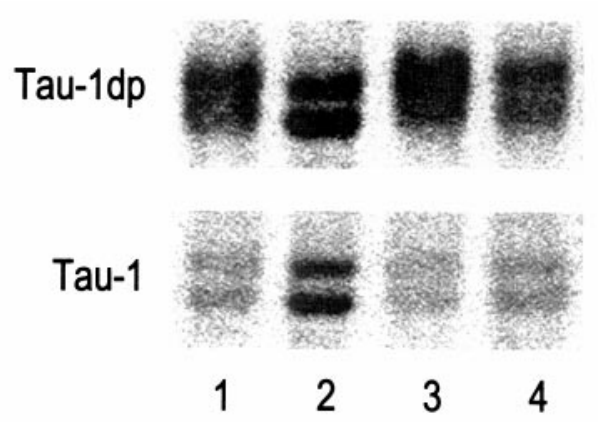

B
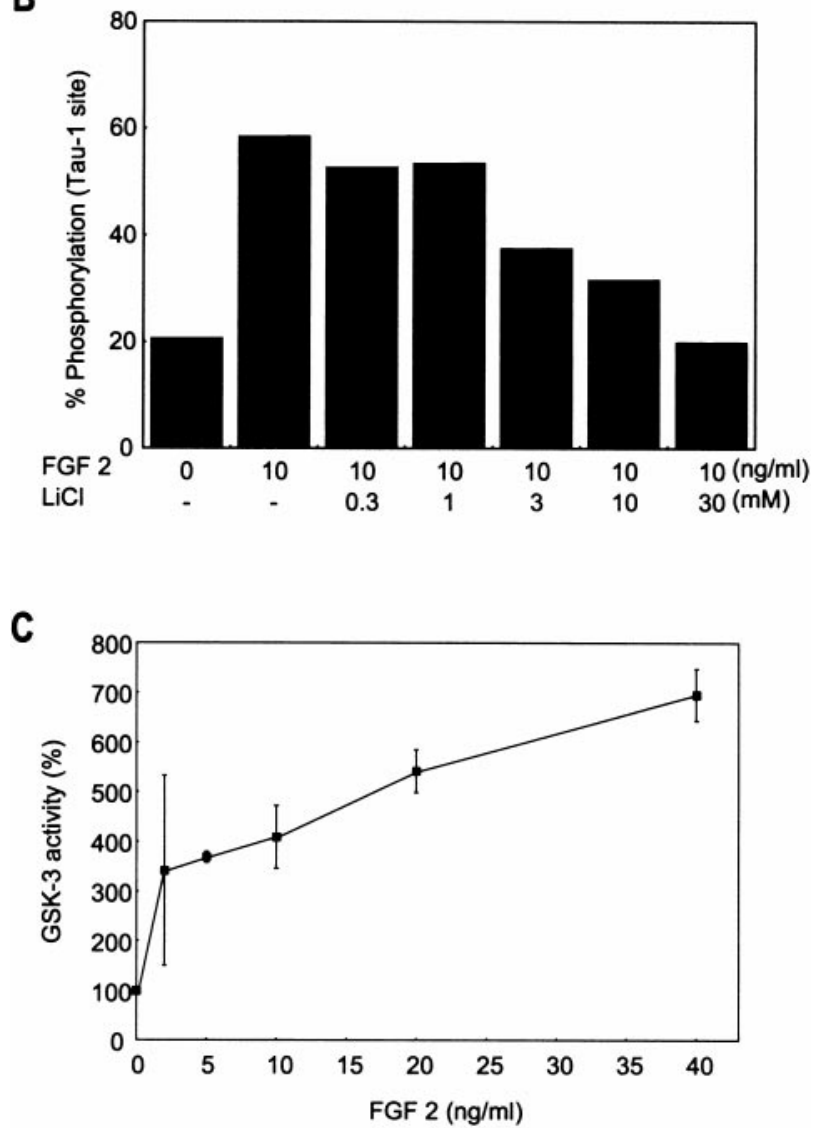

Figure 6. Phosphorylation of tau induced by FGF-2 is mediated by GSK-3. $A$, Effect of kinase inhibitors on the phosphorylation of tau induced by FGF-2. Adult progenitor cells treated with butyrolactone I (30 $\mu \mathrm{g}, 6 \mathrm{hr})$, PD98059 (50 $\mu \mathrm{g}, 60 \mathrm{~min})$, or $\mathrm{LiCl}(30 \mathrm{~mm}, 3 \mathrm{hr})$ and $10 \mathrm{ng} / \mathrm{ml}$ FGF-2 were lysed and analyzed on Western blots that had been treated with (Tau-1 dp) or without (Tau-1) alkaline phosphatase. Lane 1, Untreated; lane 2, LiCl; lane 3, butyrolactone I; lane 4, PD98059. Note that the phosphorylation at the Tau-1 site induced by FGF-2 was inhibited only by lithium, an inhibitor of GSK-3 (no upward mobility shift in lane 2 in top panel as compared with lanes $1,3,4)$. B, Dose-dependent inhibitory effect of lithium on FGF-2-mediated tau phosphorylation. Adult progenitor cells treated with indicated concentrations of LiCl for $6 \mathrm{hr}$ in $10 \mathrm{ng} / \mathrm{ml} \mathrm{FGF}-2$ were lysed, and the percentage of phosphorylation was determined from Western blots as described in Materials and Methods. The data points without $\mathrm{LiCl}$ are from Figure $3 D$. The percentage of phosphorylation was decreased by lithium in a dose-dependent manner. $C$, FGF-2 increases GSK-3 activity. GSK-3 activities were measured by using extracts from the cells that had been cultured in the indicated concentrations of FGF-2 for $7 \mathrm{~d}$. The GSK-3 activity (\%) was calculated on the basis of the value of FGF-2 at $0 \mathrm{ng} / \mathrm{ml}(n=3)$. FGF-2 increases GSK-3 activity in a dose-dependent manner. expression, but not its phosphorylation. The production of adult tau isoforms together with the ability to differentiate, on stimulation, into neuronal and/or glial cells indicates the potential of adult progenitor cells as a cell culture model to study adult neurodegenerative diseases that are characterized by an accumulation of hyperphosphorylated tau.

No tau immunoreactivity has been reported previously in undifferentiated adult progenitor cells. In this study, however, we found that these cells express abundantly the adult isoforms of tau, with the Tau-1 site highly phosphorylated. This phosphorylation was the very reason that the presence of tau in these cells had been overlooked previously. Most of the previous studies had used Tau-1 antibody, which recognizes tau only when it is dephosphorylated at the Tau- 1 site. Indeed, the same results were obtained in the present study when Tau- 1 was used without any previous treatment with alkaline phosphatase (see Fig. $1 A$ ).

The present study gives rise to several issues. First, tau expression not only is restricted to differentiated neurons but also occurs in actively dividing progenitor cells and astrocytes derived from them. Second, the expression of adult tau isoforms does not necessarily indicate the maturity of a cell. This point is demonstrated in the progenitor cells from adult hippocampus, which, although immature (nestin-positive), still produce most of the adult tau isoforms but in different proportions from those in adult rat brain tissue. On the other side of the spectrum are the progenitor cells from fetal brain, which do not seem to switch to adult tau. In contrast, in primary cultures of neonatal rat brain, changes in tau mRNA splicing and production of adult tau isoforms have been observed during 6-12 d in culture (Pizzi et al., 1995). Most likely, fetal progenitor cells are too immature developmentally and lack the factors to make in vitro the switch from fetal to adult tau.

The marked effect of FGF-2 on the expression of tau in progenitor cells from adult rat brain indicates the role of FGF-2 as a regulator of tau. This effect of FGF-2 on tau might be acquired during later stages of the development, because the increase in tau expression in the progenitor cells from fetal brain could not be observed until the fifth passage. The dynamic effect of FGF-2 on tau expression also may be of importance for postmitotic neurons. FGF-2 has been reported to have an effect on axonal formation (Walicke et al., 1986), especially axonal branching (Miyagawa et al., 1993) and in vivo sprouting in cholinergic neurons (Fagan et al., 1997). Tau is one of the major MAPs in mature neurons and is expressed abundantly in axons (Binder et al., 1985). Therefore, FGF-2 possibly may have an effect on the regulation of axonal formation, generation, and, especially, regeneration after injury by affecting tau expression and phosphorylation in adult brain.

It has been shown previously that progenitor cells differentiate into astrocytes by stimulation with CNTF, both in the presence or absence of FGF-2 (Johe et al., 1996). We studied the effect of FGF-2 on tau in astrocytes derived from CNTF-treated adult progenitor cells. As shown in Figure 5, tau is present in cultured astrocytes when they are treated with FGF-2. The tau proteins in these differentiated astrocytes also are regulated by FGF-2 as well as those in undifferentiated progenitor cells, suggesting that the effect of FGF-2 on the expression of adult tau may be more general in adult CNS. Although the mechanisms are still unclear, in some pathological conditions, including progressive supranuclear palsy, corticobasal degeneration, Pick's disease, dementia pugilistica, and Alzheimer Disease, abnormally phosphorylated tau-positive astrocytes or astrocytic processes have been reported 
to appear in the affected areas of the brain (for review, see Chin and Goldman, 1996), sometimes in parallel with overexpression of FGF-2 (Stopa et al., 1990).

In the present study we found that FGF-2 upregulates the phosphorylation of tau at the Tau-1 site in progenitor cells from adult hippocampus. This increase in tau phosphorylation is attributable mainly to the increased levels of phosphorylated tau (Fig. 3A, compare Tau-1 with Tau-1 dp). Interestingly, this pattern of increase in phosphorylated tau is similar to that in AD brain (see Khatoon et al., 1992). Furthermore, the present study shows that the increase in tau phosphorylation at this site corresponded to an increase in the activity of GSK-3 but neither MAPK nor cdks, suggesting that GSK-3 activity might be regulated by the FGF-2 signaling pathway. Unlike adult progenitor cells, these cells from fetal brain did not reveal any increase in tau phosphorylation in response to FGF-2 treatment, suggesting that the FGF-2 signaling pathway that regulates the GSK-3 activity is probably not developed in the fetal cells.

GSK-3 is believed to be a key kinase in AD involved in the hyperphosphorylation of tau, because it can induce Alzheimerlike phosphorylation in COS cells transfected with tau (Lovestone et al., 1994). In vitro Alzheimer-type phosphorylation of tau is induced by GSK-3 only in the presence of heparin or when tau is prephosphorylated with certain nonproline-dependent kinases (Moreno et al., 1995; Singh et al., 1995a,b; Sengupta et al., 1998). That not all characteristic AD tau epitopes are hyperphosphorylated in the progenitor cells with the conditions used in the present study may be attributable to differences in the kinase/ phosphatase ratios or exogenous factors such as neurotrophins or lymphokines. However, in AD, with its decreased protein phosphatase activity (Gong et al., 1993, 1995), FGF-2 might be one of the factors that play an important role in the increased tau levels (Khatoon et al., 1992) and the formation and accumulation of highly phosphorylated tau in brain (Grundke-Iqbal et al., 1986a; Iqbal et al., 1989; Lee et al., 1991; Köpke et al., 1993). Indeed, in AD brain the FGF-2 level is elevated when compared with age-matched control brain (Stopa et al., 1990), and strong FGF-2 immunoreactivity has been observed in tau lesions such as neurofibrillary tangles and dystrophic and degenerating neurites of neuritic plaques (Cummings et al., 1993). Moreover, brain injury, one of the major risk factors of $\mathrm{AD}$ and probably the cause of dementia pugilistica, also is known to increase the expression of FGF-2 (Finklestein et al., 1988; Frautschy et al., 1991; Logan et al., 1992). Furthermore, continuous upregulation of FGF-2 in brain might be critical because it can induce not only an initial accumulation of hyperphosphorylated tau but also continuous activation of GSK-3. Increased GSK-3 activity has been reported to induce cholinergic dysfunction in primary cultured neurons (Hoshi et al., 1996) and apoptosis in PC12 cells (Pap and Cooper, 1998), both reported to occur in AD neuropathology. GSK-3 also is involved in the regulation of diverse transcription factors, which also might be affected by increased GSK-3 activity.

In conclusion, FGF-2 upregulates the expression and phosphorylation of tau in progenitor cells and differentiated astrocytes from adult, but not fetal, rat hippocampus. The hyperphosphorylation of tau produced by FGF-2 in these cells occurs via upregulation of GSK-3 activity but neither MAPK nor cdks activities. These findings identify a new role of FGF-2 both in normal neurobiology and in neurodegenerative diseases characterized by the accumulation of hyperphosphorylated tau.

\section{REFERENCES}

Alessi DR, Cuenda A, Cohen P, Dudley DT, Saltiel AR (1995) PD 098059 is a specific inhibitor of the activation of mitogen-activated protein kinase kinase in vitro and in vivo. $\mathrm{J}$ Biol Chem 270:27489-27494.

Alonso AC, Zaidi T, Grundke-Iqbal I, Iqbal K (1994) Role of abnormally phosphorylated tau in the breakdown of microtubules in Alzheimer disease. Proc Natl Acad Sci USA 91:5562-5566.

Bensadoun A, Weinstein D (1976) Assay of proteins in the presence of interfering materials. Anal Biochem 70:241-250.

Binder LI, Frankfurter A, Rebhun LI (1985) The distribution of tau in the mammalian central nervous system. J Cell Biol 101:1371-1378.

Brewer GJ (1997) Isolation and culture of adult rat hippocampal neurons. J Neurosci Methods 71:143-155.

Chin SS, Goldman JE (1996) Glial inclusions in CNS degenerative diseases. J Neuropathol Exp Neurol 55:499-508.

Cummings BJ, Su BJ, Cotman CW (1993) Neuritic involvement within bFGF immunopositive plaques of Alzheimer's Disease. Exp Neurol 124:315-325.

Drewes G, Lichtenberg-Kraag B, Doering F, Mandelkow EM, Biernat J, Goris J, Doree M, Mandelkow E (1992) Mitogen-activated protein (MAP) kinase transforms tau protein into an Alzheimer-like state. EMBO J 11:2131-2138.

Fagan AM, Suhr ST, Lucidi-Phillipi CA, Peterson DA, Holtzman DM, Gage FH (1997) Endogenous FGF-2 is important for cholinergic sprouting in the denervated hippocampus. J Neurosci 17:2499-2511.

Finklestein SP, Apostolides PJ, Caday CG, Prosser J, Philips MF, Klagsbrun M (1988) Increased basic fibroblast growth factor (bFGF) immunoreactivity at the site of focal brain wounds. Brain Res 460:253-259.

Frautschy SA, Walicke PA, Baird A (1991) Localization of basic fibroblast growth factor and its mRNA after CNS injury. Brain Res 553:291-299.

Gage FH, Coates PW, Palmer TD, Kuhn HG, Fisher LJ, Suhonen JO, Peterson DA, Suhr ST, Ray J (1995) Survival and differentiation of adult neuronal progenitor cells transplanted to the adult brain. Proc Natl Acad Sci USA 92:11879-11883.

Goedert M, Spillantini MG, Potier MC, Ulrich J, Crowther RA (1989) Cloning and sequencing of the cDNA encoding an isoform of microtubule-associated protein tau containing four tandem repeats: differential expression of tau protein mRNA in human brain. EMBO J 8:393-399.

Gong CX, Singh TJ, Grundke-Iqbal I, Iqbal K (1993) Phosphoprotein phosphatase activities in Alzheimer disease brain. J Neurochem 61:921-927.

Gong CX, Shaikh S, Wang JZ, Zaidi T, Grundke-Iqbal I, Iqbal K (1995) Phosphatase activity toward abnormally phosphorylated tau: decrease in Alzheimer disease brain. J Neurochem 65:732-738.

Greenberg SG, Davies P, Schein JD, Binder LI (1992) Hydrofluoric acid-treated tau PHF proteins display the same biochemical properties as normal tau. J Biol Chem 267:564-569.

Grundke-Iqbal I, Iqbal K, Tung YC, Quinlan M, Wisniewski HM, Binder LI (1986a) Abnormal phosphorylation of the microtubule-associated protein tau in Alzheimer cytoskeletal pathology. Proc Natl Acad Sci USA 83:4913-4917.

Grundke-Iqbal I, Iqbal K, Quinlan M, Tung YC, Zaidi MS, Wisniewski HM (1986b) Microtubule-associated protein tau: a component of Alzheimer paired helical filaments. J Biol Chem 261:6084-6089.

Grundke-Iqbal I, Vorbrodt AW, Iqbal K, Tung YC, Wang GP, Wisniewski HM (1988) Microtubule-associated polypeptides tau are altered in Alzheimer paired helical filaments. Mol Brain Res 4:43-52.

Hanger DP, Hughes K, Woodgett JR, Brion JP, Anderton BH (1992) Glycogen synthase kinase-3 induces Alzheimer's disease-like phosphorylation of tau: generation of paired helical filament epitopes and neuronal localization of the kinase. Neurosci Lett 147:58-62.

Hasegawa M, Watanabe A, Takio K, Suzuki M, Arai T, Titani K, Ihara Y (1993) Characterization of two distinct monoclonal antibodies to paired helical filaments: further evidence for fetal-type phosphorylation of the tau in paired helical filaments. J Neurochem 60:2068-2077.

Hoshi M, Takashima M, Noguchi A, Maruyama M, Sato M, Kondo S, Saitoh Y, Ishiguro K, Hoshino T, Imahori K (1996) Regulation of mitochondrial pyruvate dehydrogenase activity by tau protein kinase I/glycogen synthase kinase $3 \beta$ in brain. Proc Natl Acad Sci USA 93:2719-2723.

Hosoi T, Uchiyama M, Okumura E, Saito T, Ishiguro K, Uchida T, Okuyama A, Kishimoto T, Hisanaga S (1995) Evidence for cdk5 as a 
major activity phosphorylating tau protein in porcine brain extract. J Biochem (Tokyo) 117:741-749.

Iqbal K, Grundke-Iqbal I, Zaidi T, Merz PA, Wen GY, Shaikh SS, Wisniewski HM, Alafuzoff I, Winblad B (1986) Defective brain microtubule assembly in Alzheimer's disease. Lancet 2:421-426.

Iqbal K, Grundke-Iqbal I, Smith AJ, George L, Tung YC, Zaidi T (1989) Identification and localization of a tau peptide to paired helical filaments of Alzheimer disease. Proc Natl Acad Sci USA 86:5646-5650.

Iqbal K, Alonso AC, Gong CX, Khatoon S, Singh TJ, Grundke-Iqbal I (1994) Mechanism of neurofibrillary degeneration in Alzheimer's disease. Mol Neurobiol 9:119-123.

Johe KK, Hazel TG, Muller T, Dugich-Djordjevic MM, McKay RD (1996) Single factors direct the differentiation of stem cells from fetal and adult central nervous system. Genes Dev 10:3129-3140.

Kalcheva N, Weidenheim KM, Kress Y, Shafit-Zagardo B (1997) Expression of microtubule-associated protein-2a and other novel microtubule-associated protein-2 transcripts in human fetal spinal cord. J Neurochem 68:383-391.

Khatoon S, Grundke-Iqbal I, Iqbal K (1992) Brain levels of microtubuleassociated protein tau are elevated in Alzheimer's disease: a radioimmuno-slot-blot assay for nanograms of the protein. J Neurochem 59:750-753.

Klein PS, Melton DA (1996) A molecular mechanism for the effect of lithium on development. Proc Natl Acad Sci USA 93:8455-8459.

Köpke E, Tung YC, Shaikh S, Alonso AC, Iqbal K, Grundke-Iqbal I (1993) Microtubule-associated protein tau: abnormal phosphorylation of a non-paired helical filament pool in Alzheimer disease. J Biol Chem 268:24374-24384.

Kosik KS, Orecchio LD, Bakalis S, Neve RL (1989) Developmentally regulated expression of specific tau sequences. Neuron 2:1389-1397.

Lee G, Cowan N, Kirschner M (1988) The primary structure and heterogeneity of tau protein from mouse brain. Science 239:285-288.

Lee VM, Balin BJ, Otvos Jr L, Trojanowski JQ (1991) A68: a major subunit of paired helical filaments and derivatized forms of normal tau. Science 251:675-678.

Lindwall G, Cole RD (1984) Phosphorylation affects the ability of tau protein to promote microtubule assembly. J Biol Chem 259:5301-5305.

Logan A, Frautschy SA, Gonzalez AM, Baird A (1992) A time course for the focal elevation of synthesis of basic fibroblast growth factor and one of its high-affinity receptors (flg) following a localized cortical brain injury. J Neurosci 12:3828-3837.

Lovestone S, Reynolds CH, Latimer D, Davis DR, Anderton BH, Gallo JM, Hanger D, Mulot S, Marquart B, Stabel S, Woodgett JR, Miller CCJ (1994) Alzheimer's disease-like phosphorylation of the microtubule-associated protein tau by glycogen synthase kinase- 3 in transfected mammalian cells. Curr Biol 4:1077-1086.

McKay RD (1997) Stem cells in the central nervous system. Science 276:66-71.

Miyagawa T, Saito H, Nishiyama N (1993) Branching enhancement by basic fibroblast growth factor in cut neurites of hippocampal neurons. Neurosci Lett 153:29-31.

Moreno FJ, Munoz-Montano JR, Avila J (1995) Glycogen synthase kinase-3 phosphorylation of different residues in the presence of different factors: analysis on tau protein. Mol Cell Biochem 165:47-54.
Otvos Jr L, Feiner L, Lang E, Szendrei GI, Goedert M, Lee VM (1994) Monoclonal antibody PHF-1 recognizes tau protein phosphorylated at serine residues 396 and 404. J Neurosci Res 39:669-673.

Palmer TD, Takahashi J, Gage FH (1997) The adult rat hippocampus contains primordial neural stem cells. Mol Cell Neurosci 8:389-404.

Pap M, Cooper GM (1998) Role of glycogen synthase kinase-3 in the phosphatidylinositol 3-kinase/Akt cell survival pathway. J Biol Chem 273:19929-19932.

Pei JJ, Tanaka T, Tung YC, Braak E, Iqbal K, Grundke-Iqbal I (1997) Distribution, levels, and activity of glycogen synthase kinase-3 in the Alzheimer disease brain. J Neuropathol Exp Neurol 56:70-78.

Pizzi M, Valerio A, Belloni M, Arrighi V, Alberici A, Liberini P, Spano P, Memo M (1995) Differential expression of fetal and mature tau isoforms in primary cultures of rat cerebellar granule cells during differentiation in vitro. Mol Brain Res 34:38-44.

Sah DW, Ray J, Gage FH (1997) Regulation of voltage- and ligandgated currents in rat hippocampal progenitor cells in vitro. J Neurobiol 32:95-110.

Sánchez C, Díaz-Nido J, Avila J (1995) Variations in in vivo phosphorylation at the proline-rich domain of the microtubule-associated protein 2 (MAP2) during rat brain development. Biochem J 306:481-487.

Sengupta A, Kabat J, Novak M, Wu Q, Grundke-Iqbal I, Iqbal K (1998) Phosphorylation of tau at both $\mathrm{Thr}^{231}$ and $\mathrm{Ser}^{262}$ is required for maximal inhibition of its binding to microtubules. Arch Biochem Biophys 357:299-309.

Seubert P, Mawal-Dewan M, Barbour R, Jakes R, Goedert M, Johnson GV, Litersky JM, Schenk D, Leiberburg I, Trojanowski JQ, Lee VM (1995) Detection of phosphorylated Ser ${ }^{262}$ in fetal tau, adult tau, and paired helical filament tau. J Biol Chem 270:18917-18922.

Singh TJ, Zaidi T, Grundke-Iqbal I, Iqbal K (1995a) Modulation of GSK-3-catalyzed phosphorylation of microtubule-associated protein tau by non-proline-dependent protein kinases. FEBS Lett 358:4-8.

Singh TJ, Haque N, Grundke-Iqbal I, Iqbal K (1995b) Rapid Alzheimerlike phosphorylation of tau by the synergistic actions of non-prolinedependent protein kinases and GSK-3. FEBS Lett 358:267-272.

Stopa EG, Gonzalez AM, Chorsky R, Corona RJ, Alvarez J, Bird ED, Baird A (1990) Basic fibroblast growth factor in Alzheimer's disease. Biochem Biophys Res Commun 171:690-696.

Szendrei GI, Lee VM, Otvos Jr L (1993) Recognition of the minimal epitope of monoclonal antibody Tau-1 depends upon the presence of a phosphate group but not its location. J Neurosci Res 34:243-249.

Tohyama T, Lee VM, Rorke LB, Marvin M, McKay RD, Trojanowski JQ (1992) Nestin expression in embryonic human neuroepithelium and in human neuroepithelial tumor cells. Lab Invest 66:303-313.

Vuilliet R, Halloran SM, Braun RK, Smith AJ, Lee G (1992) Prolinedirected phosphorylation of human tau protein. J Biol Chem 267:22570-22574.

Walicke P, Cowan WM, Ueno N, Baird A, Guillemin R (1986) Fibroblast growth factor promotes survival of dissociated hippocampal neurons and enhances neurite extension. Proc Natl Acad Sci USA 83:3012-3016.

Yoshida H, Ihara Y (1993) Tau in paired helical filaments is functionally distinct from fetal tau: assembly incompetence of paired helical filament-tau. J Neurochem 61:1183-1186. 